\title{
REAL-TIME POLYMERASE CHAIN REACTION FOR DETECTION OF OPTIMAL THERMAL PROFILE FOR DNA TEMPLATES FROM AIR-DRIED INSECT COLLECTION MATERIAL
}

\author{
Inese Kokina\#, Arvīds Barševskis, Rita Latvele, Kristīna Aksjuta, and Inese Jahundoviča \\ Institute of Life Sciences and Technologies, Daugavpils University, Parādes iela 1A, Daugavpils, LV-5401, LATVIA \\ inese.kokina@du.lv \\ \# Corresponding author
}

Contributed by Arvīds Barševskis

\begin{abstract}
The thermal profile for polymerase chain reaction (PCR) technique is the main concern in obtaining the PCR product. Determination of optimal thermal profile can be achieved by various techniques, the main objectives of which are simplicity and cost effectiveness of the method. Real-time PCR is a novel molecular biology method widely used in different fields, recognised by its accuracy and precision. In the present work, the thermal profile was estimated for DNA from air-dried collection material of Notiophilus genus and new sequences were obtained for GeneBank. Air-dried entomological collections exist around the world and the use of DNA from such type of material is widespread and offers various unique preferences. The purpose of the study was to assess the suitability of different primer annealing temperatures $\left(42^{\circ} \mathrm{C}-55^{\circ} \mathrm{C}\right)$ for universal mitochondrial DNA COI gene primer pair HCO/LCO using real-time PCR method. During this study we demonstrate that real-time PCR could be useful to determine the optimal thermal profile for low-yield DNA for increasing the number of qualitative DNA sequences.
\end{abstract}

Key words: rtPCR conditions, COI gene, mtDNA, Notiophilus.

\section{INTRODUCTION}

There have been numerous molecular studies using museum collections of microbes, invertebrates, vertebrates, and plants (Willerslev et al., 2004; Willerslev and Cooper, 2005). Insects, the most diverse animal group in the world, have several disadvantages for obtaining high-yield DNA for genetic studies from air-dried collections (Goldstein and DeSalle, 2003; Harper et al., 2006; Watts et al., 2007). Insects are passed through a series of pretreatments before preservation in the collection, which can affect the specimen DNA for extraction procedures (Lindahl, 1993). Chitin is one of the known DNA extraction reaction inhibitors for beetles, due to the natural aminopolysaccharide, which is a unique structural component of exoskeleton (Merzedorfer, 2013).

In systematic collections, there are series of specimens that are documented to retain their scientific value. The systematic collections are represented in the same way as a research library (Mandriolo, 2008; VanHardenbroek et al., 2012). Many phylogenetic, taxonomic and ecological studies are based on using previously collected specimens (Winker 2004; Wandeler et al., 2007).

Systematics is usually interested in historical classifications, specified classifications of the natural hierarchy that include the tree of life. Molecular systematics involves many approaches in which phylogenetic relationships are included by using information from molecular sequences of the organisms under study (Lemey et al., 2009; Wiley and Lieberman, 2011). Nowadays, air-dried collection material is used for different studies of evolution, ecology and systematics (Krishtalka et al., 2000; Suarez \& Tsutsui, 2004; Thomsen et al., 2009).

However, numerous studies depend on species identification and phylogenetic relationships, which are based on molecular methods. Various molecular protocols have been developed, but most of them should be optimized for specific specimens (Maddison et al., 1999; Calderon-Cortes et al., 2010; Kotze et al., 2011).

Ground beetles are the most diverse and the best known of Latvian beetles. Ground beetles have been studied in Latvia for more than two centuries (Barševskis, 2003) and there is an epoch of combined studies of morphology, ecology and molecular biology. There are described 57 species of Notiophilus genus in the world, of which 47 are distributed in Palearctic, 16 in Nearctic, and 2 in Neotropical regions (Barševskis, 2007).

Various molecular methods have been developed for obtaining high-yield DNA from air-dried collection specimens 
(Gilbert et al., 2007; Watts et al., 2007). DNA extraction from ancient insects is limited by the destructive sampling methods, which may destroy important morphological characteristics. Many museum specimens have suffered from such sampling procedures, but there are several methods to obtain DNA by using non-destructive sampling methods (Rohland et al., 2004; Gilbert et al., 2007; Thomsen et al., 2009).

A huge number of universal primers for ground beetles have been produced. These primers provide a possibility to study variable regions of DNA for molecular studies of species identification or molecular phylogenetics (Howland and Hewitt, 1995; Maddison et al., 2009). Universal primers for several genes are effective in research of little-known species. In cases of using universal primers, it is necessary to optimise the thermal profile for samples (Sipos et al., 2006; Raupach et al., 2010). In general, the primer annealing temperature is a critical parameter in the PCR thermal profile. The universal primer pair LCO/HCO has been used in studies for several species using the mitochondrial DNA cytochrome oxidase I. The most popular primers for mitochondrial DNA genes are for specimens from air-dried collection materials (Gilbert et al., 2007; Thomsen et al., 2009). This might be because the amount of isolated mitochondrial DNA is higher than the amount of nuclear DNA from airdried collection material (Goldsen and DeSalle, 2003; Gavarāne et al., 2011). The LCO/HCO primer pair has been used in many studies, but the used primers annealing temperature differs in the range from $42{ }^{\circ} \mathrm{C}$ to $55^{\circ} \mathrm{C}$ (Dahlgren et al., 2000; Kelly et al., 2007; Margam et al., 2010; Muller and Beheregaray, 2010; Sun et al., 2012).

If the optimal thermal profile is unknown, one of the possibilities is to use gradient PCR, but many trials are needed in a single experiment. Gel electrophoresis is used for gradient polymerase chain reaction (PCR) product visualisation (Lueders and Friedrich, 2003). In cases when real-time PCR method is used, it is possible to analyse the data without using special visualisation. In real-time PCR the reaction is monitored during the process by monitoring the fluorescence of dyes using special software (Burnt et al., 2005; Yuan et al., 2006).

As the name suggests, real time PCR is a technique used to record the changes of a PCR reaction in real time. A relatively small amount of PCR product can be quantified by using this method. Nowadays, real-time PCR technique has reached a level of sensitivity, correctness and practical simplicity that allows using it as bioinstrumentation (Bustin et al., 2005; Wong and Medrano, 2005). Routine uses of real-time PCR include approbation of PCR conditions, species identification analysis, gene expression analysis, pathogen detection, single nucleotide polymorphism (SNP) analysis, analysis of chromosome aberrations and protein detection by real-time immuno PCR (Kubista et al., 2006; VanGuilder, 2008). Optimal usage of these advantages requires understanding of the many options available for running a real-time PCR experiment (Wong and Medrano, 2005). Real-time PCR using SYBR Green I combine the ease and necessary precision to be able to produce reliable and rapid results. Two figures of real-time PCR $-C t$ and Melt characterize the success of reaction (Yuan et al., 2008). In this study, these two figures were analyzed to estimate the different primer annealing temperatures for each sample. We aim to investigate the $\mathrm{HCO} / \mathrm{LCO}$ primer annealing temperature for DNA samples obtained from air-dried collection material of Notiophilus beetles from various regions of the world.

\section{MATERIALS AND METHODS}

Taxa being examined. Forty-eight samples of Notiophilus genus from air-dried collection material in the Daugavpils University Institute of Systematic Biology were analysed in this study: 24 samples of $N$. aquaticus from Russia (collected during 1989-2008), 12 samples of $N$. semenovi from Kirgizstan (collected in 1991) and 12 samples of $N$. jakovlevi from Russia (collected in 1998). The Notiophilus genus species were identified by one of the authors (A. Barševskis) from Daugavpils University Institute of Systematic Biology, Latvia.

DNA extraction and quantification. DNA extraction was carried out with the DNeasy Blood and Tissue extraction kit (Qiagen, Germany). The optimised method for DNA isolation from air-dried collection material by Gavarāne et al., 2011 was used. During this study, the final elution volume of DNA was increased to $200 \mu \mathrm{l}$. This was needed, because the number of amplifications was high.

DNA was quantified by spectrophotometer method with a NanoDrop1000 (ThermoScientific Fisher, Finland) as recommended by the manufacturer. DNA samples used for a given PCR were quantified for all reactions. The Abs260/280 and Abs 260/230 ratios for the genomic DNA were determined with NanoDrop1000 (ThermoScientific Fisher, Finland).

Real-time PCR. PCR conditions for each sample were approbating using real-time PCR method. For real-time PCR, the $25 \mu \mathrm{l}$ volume contained 1x QuantiFast SYBR Green PCR Master Mix (Qiagen, Germany), $1 \mu \mathrm{M}$ of forward

LCO1490 (5'-GGTCAACAAATCATAAAGATATTGG-3') and $1 \mu \mathrm{M}$ of reverse

HCO2198 (5'-TAAACTTCAGGGTGACCAAAAAATCA-3') primer and $25 \mathrm{ng}$ of genomic DNA. PCR was run using a SmartCycler (Cepheid, USA) real-time PCR system. Negative and positive controls were included with each round of reactions. The amplification profile for $\mathrm{COI}$ is shown in Table 1. All real time PCR reactions were carried out in triplicate for each DNA extract by using eight different annealing temperatures from $42{ }^{\circ} \mathrm{C}$ to $55{ }^{\circ} \mathrm{C}$. The melting curve analysis and cycle threshold $(C t)$, which refers to the cycle number where the fluorescence of sample significantly increases above the background level, was calculated automatically by the SmartCycler software (Cepheid, USA) as the first maximum of the second derivative of the curve. 
Table 1

REAL-TIME PCR AMPLIFICATION PROFILE

\begin{tabular}{l|c|l}
\hline \multicolumn{1}{c|}{ Parameter } & Time & \multicolumn{1}{c}{ Temperature } \\
\hline PCR initial activation step & $15 \mathrm{~min}$ & $95^{\circ} \mathrm{C}$ \\
Number of cycles 35 & & \\
Denaturation & $15 \mathrm{~s}$ & $94^{\circ} \mathrm{C}$ \\
Primer annealing & $30 \mathrm{~s}$ & $42^{\circ} \mathrm{C} ; 45^{\circ} \mathrm{C} 47^{\circ} \mathrm{C} ; 49{ }^{\circ} \mathrm{C} ; 50{ }^{\circ} \mathrm{C} ;$ \\
& & $51^{\circ} \mathrm{C} ; 52^{\circ} \mathrm{C} ; 55^{\circ} \mathrm{C}$ \\
Extension & $30 \mathrm{~s}$ & $72{ }^{\circ} \mathrm{C}$ \\
\hline
\end{tabular}

PCR, polymerase chain reaction

The measurement of fluorescence is related to the amount of amplicon in the reaction.

Conventional PCR and sequencing. Amplification was performed in an AB Veriti Thermal Cycler (Applied Biosystems, USA) using a Taq PCR Core Kit (Qiagen, Germany). Qiagen Taq DNA polymerase was used in $25-\mu$ reactions with magnesium concentration adjusted to 2.0 $\mathrm{mmol} / \mathrm{L}$. The PCR cycling consisted of a 3-min initial denaturation at $94{ }^{\circ} \mathrm{C}$, followed by 30 additional cycles of $45 \mathrm{~s}$ denaturation at $94{ }^{\circ} \mathrm{C}$, annealing for $30 \mathrm{~s}$, extension for 1 min at $72{ }^{\circ} \mathrm{C}$, and then $10 \mathrm{~min}$ of final extension at $72{ }^{\circ} \mathrm{C}$. Negative and positive controls were included with each round of reactions.

The PCR amplification products were separated and visualized by an automated gel electrophoresis system QIAxcel and QIAxcel DNA High Resolution Kit (Qiagen, Germany) was used.

PCR products were cleaned-up by ExoSAP-IT (Affymetrix, USA) according to the manufacture protocol. Amplified PCR products were sequenced using an ABI 3130xl (Applied Biosystems, USA) capillary sequencer using BigDye Terminator v3.1 chemistry and for purification sequencing products BigDye XTerminator chemestry (Applied Biosystems, USA). Sequencing reactions used the same primers as for amplification. All sequences of the three species were aligned using SeqScape version 2.5 (Applied Biosystems, USA) with default settings. All sequences were identified by the online BLAST search tool.

\section{RESULTS}

In total, 48 adult specimens of Notiophilus collected from different locations and stored in air-dried collection, were used to detect the optimal $\mathrm{HCO} / \mathrm{LCO}$ primer annealing temperature.

The mean DNA concentration was $9.16 \pm 0.78(\mathrm{SE}) \mathrm{ng} / \mu \mathrm{l}$ for $N$. aquaticus $(\mathrm{n}=24), 16.33 \pm 1.22(\mathrm{SE}) \mathrm{ng} / \mu \mathrm{l}$ for $N$. semenovi $(\mathrm{n}=12)$, and $12.44 \pm 0.92(\mathrm{SE})$ for $N$. jakovlevi $(\mathrm{n}=12) \mathrm{ng} / \mu \mathrm{l}$. The mean Abs260/280 was $1.29 \pm 0.03$ (SE) for $N$. aquaticus $(\mathrm{n}=24), 1.86 \pm 0.07$ (SE) for $N$. semenovi $(\mathrm{n}=12)$, and $1.94 \pm 0.02(\mathrm{SE})$ for $N$. jakovlevi $(\mathrm{n}=12)$. The mean Abs260/230 was $0.93 \pm 0.08$ (SE) for $N$. aquaticus $(\mathrm{n}=24), 1.96 \pm 0.03(\mathrm{SE})$ for $N$. semenovi $(\mathrm{n}=12)$, and

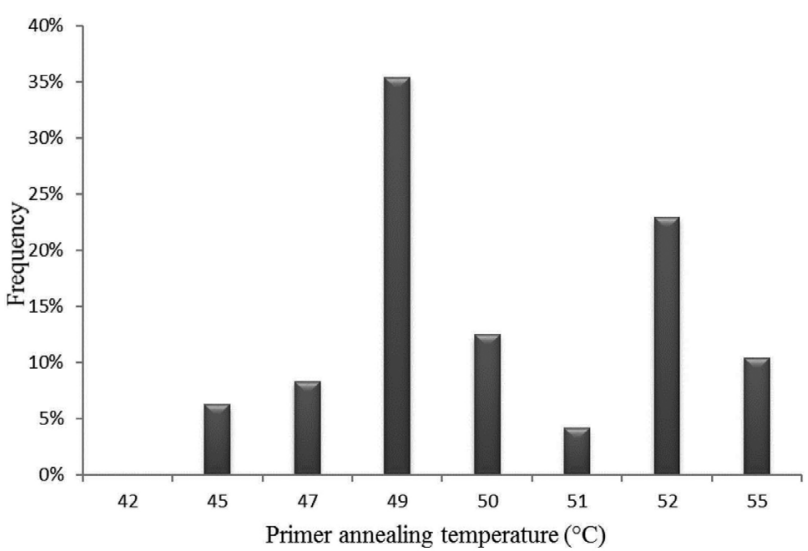

Fig. 1. Polymerase chain reaction efficiency using different primer annealing temperatures.

$1.39 \pm 0.09(\mathrm{SE})$ for $N$. jakovlevi $(\mathrm{n}=12)$. Clean DNA (Demeke et al., 2009; Demeke et al., 2012) was shown by an Abs260/280 ratio $\geq 1.8$ and Abs260/230 ratio $\geq 2.0$.

Eight different primer annealing temperatures $\left(42{ }^{\circ} \mathrm{C}\right.$; $45{ }^{\circ} \mathrm{C} 47{ }^{\circ} \mathrm{C} ; 49{ }^{\circ} \mathrm{C} ; 50{ }^{\circ} \mathrm{C} ; 51{ }^{\circ} \mathrm{C} ; 52{ }^{\circ} \mathrm{C}$, and $55^{\circ} \mathrm{C}$ ) for universal mtDNA primer pair $\mathrm{HCO} / \mathrm{LCO}$ were tested. According to $C t$ values, a $42{ }^{\circ} \mathrm{C}$ primer annealing temperature was unsuitable for air-dried collection material. The $49{ }^{\circ} \mathrm{C}$ primer annealing temperature was suitable for $35.42 \%$ of samples and $52{ }^{\circ} \mathrm{C}$ primer annealing temperature for $22.92 \%$ (Fig. 1). The $49{ }^{\circ} \mathrm{C}$ and $52{ }^{\circ} \mathrm{C}$ primer annealing temperatures showed the most successful results in PCR reaction for air-dried collection material. Melting curve analysis displayed contaminating DNA or primer dimers as an additional peak separate from the desired amplicon peak. The changes of melting curve depended on analysed primer annealing temperatures. The reaction $C t$ and Melt data and the electrophoresis data demonstrated that one appropriate primer annealing temperature is optimal for each sample.

In total, sequences from air-dried collection material were recovered from 36 of the 48 specimens examined. Complete sequences for three species were obtained. Three new sequences were directly submitted to the International database of molecular sequences GenBank. Accession numbers for nucleotide sequences are for N. aquaticus - KF060716, N. semenovi - KF060717 and N. jakovlevi - KF060718.

\section{DISCUSSION}

The success rate of PCR depends on many factors, such as DNA template, PCR conditions and reagents for reaction. We demonstrated that real-time PCR technique is useful for optimising the amplification profile for conventional PCR. In our case we focused on the primer annealing temperature, but different amount of Taq polymerase (Alvarez et al., 2007) can be used for reaction optimisation. Success of the PCR reaction is the guaranteed prerequisite to obtain qualitative DNA sequences. The DNA primers LCO1490 and $\mathrm{HCO} 2198$ of the mitochondrial cytochrome oxidase subunit I gene from a broad range of invertebrates have 
been amplified to at least a 650 bp region (Folmer et al., 1994). We are presently using these primers to examine the possibility to detect optimal primer annealing temperature by using real-time PCR. Also we are investigating the utility of this COI fragment for species identification of air-dried collection material.

Analyses of the differences in mtDNA are popular, because all mitochondrial DNA (mtDNA) is generally passed from female to offspring without recombination, it has a high speed of evolution process, significant interspecies polymorphism and has many copies (Morlais and Severson, 2002; Galtier et al., 2009; Hendrich et al., 2010). Especially samples from air dried collection material are actually use mtDNA genes.

According to observed DNA quality, the DNA template of air-dried collection material is not high-yield and it is necessary to optimise molecular protocols to obtain good quality sequences for a routine analysis. Unfortunately, DNA yield and quality is not the limiting factor for PCR reaction. For example, a low Abs260/230 ratio indicates presence of the contaminants, mostly of carbohydrates (absorbance near $230 \mathrm{~nm}$ ), but this has no influence on PCR reaction (Lindahl, 1993; Demeke et al., 2012).

It seems likely that DNA degradation in dead tissue occurs, which depends on many factors such as storage conditions, absolute age, collection method and how it was euthanised (e.g. ethyl acetate, ethyl alcohol, formalin, cyanide) (Gilbert et al., 2007; Watts et al., 2007). The range of DNA quantity and purity can be explained by specimen collection methods and storage conditions. Almost no specimens labels include such of information, so we could not determine effects of collection/storage conditions and PCR success.

It is difficult to predict which samples from air-dried collection material will be usable for molecular analysis. Such types of samples should be analyzed several times to ensure the quality of the data. For some samples it is possible that PCR reliability may be enhanced, for example, by optimising the PCR profile, increasing the amount of template, using E. coli colonies or double PCR (Folmer et al., 1994; Thomsen et al., 2009; Gavarāne et al., 2011; Demeke et al., 2012). Real-time PCR could be used for samples that have low success of amplification, as it allows to control the reaction profile and to determine parameters associated with the effectiveness of reaction. Results obtained by using this method could be analyzed using two parameters by software despite using gradient PCR, there we are able to make conclusions about the presence of the required PCR product.

Until recently, almost all systematic studies were based on morphological and ecological studies. Now molecular biology methods are crucial as a tool in taxonomy studies. The numbers of described species are increasing rapidly causing taxonomic inflation (Isaac et al., 2004). Hence, the knowledge of taxonomy is incomplete (Alroy, 2003) and it is significant to use not only fresh material, but also air-dried col- lection material/ancient species to develop the international databases of molecular sequences.

\section{ACKNOWLEDGEMENTS}

Financial support for this study was provided by the project of European Social Fund

(No. 2009/0206/1DP/1.1.1.2.0/09/APIA/VIAA/010).

\section{REFERENCES}

Alroy, J. (2003). Taxonomic inflation and body mass distributions in North American fossil mammals. J. Mammal., 84, 431-443.

Alvarez, M. J., Vila-Ortiz, G. J., Salibe, M. C., Podhajcer, O. L., Pitossi, F.J. (2007). Model based analysis of real-time PCR data from DNA binding dye protocols. BioMed Central Bioinformatics, 8, 85-95.

Barševskis, A. (2003). Latvijas skrejvaboles (Coleoptera: Carabidae, Trachypachidae \& Rhysodidae) [Ground beetles (Coleoptera: Carabidae, Trachypachidae \& Rhysodidae) of Latvia]. Daugavpils: Baltic Institute of Coleopterology. 264 lpp. (in Latvian).

Barševskis, A. (2007). Biogeography of the genus Notiophilus Dumeril, 1806 (Coleoptera: Carabidae). Baltic J. Coleopterol., 7 (1), 121-135.

Burns, M. J., Nixon, G. J., Foy, C. A., Harris, N. (2005). Standardisation of data from real-time quantitative PCR methods - evaluation of outliers and comparison. BioMed Central Biotechnol., 5, 31-44.

Bustin, S. A., Benes, V., Nolan, T., Pfaffl, M. W. (2005). J. Mol. Endocrinol. 34, 597-601.

Calderon-Cortes, N., Quesada, M., Cano-Camacho, H., Zavala-Paramo, G. (2010). A simple and rapid method for DNA isolation from Xylophagus insects. Int. J. Mol. Sci., 11, 5056-5064.

Dahlgren, T. G., Lundberg, J., Pleijel, F., Sundberg, P. (2000). Morphological and molecular evdience of the phylogeny of Nereidiform polychaetes (Annelida). J. Zool. Syst. Evol. Res., 38 (4), 249-253.

Demeke, T., Ratnayaka, I., Phan, A. (2009). Effects of DNA extraction and purification methods on real-time quantitative PCR analysis of roundup ready soybean. J. Assoc. Offic. Anal. Chem. Int., 92 (4), 1136-1144.

Demeke, T., Ratnayaka, I., Holigroski, M., Phan, A. (2012). Assessment of DNA extraction methods for PCR testing of discontinued or unapproved biotech events in single seeds of canola, flax and soybean. Food Control, 24 (1-2), 44-49.

Folmer, O., Black, M., Hoeh, W., Lutz, R., Vrijenhoek R. (1994). DNA primers for amplification of mitochondrial cytochrome $c$ oxidase subunit I from diverse metazoan invertebrates. Mol. Mar. Biol. Biotechnol., 3 (5), 294-299.

Galtier, N., Nabholz, B., Glémin, S., Hurst, G. D. (2009). Mitochondrial DNA as a marker of molecular diversity: A reappraisal. Mol. Ecol., 18 (22), 4541-4550.

Gavarāne, I., Kokina, I., Aksjuta, K., Barševskis, A., Valainis, U. (2011). Optimization of DNA extraction protocol for DNA isolation from air-dried collection material for further phylogenetic analysis (Coleoptera: Carabidae). Acta Biol. Univ. Daugavpils, 11 (2), 141-147.

Gilbert, M. T. P., Moore, W., Melchior, L., Worobey, M. (2007). DNA extraction from dry museum beetles without conferring external morphological damage. PLoS ONE (Public Library of Science One) , 2 (3), e272.

Goldstein, P. Z., DeSalle R. (2003). Calibrating phylogenetic species formation in a threatened insect using DNA from historical specimens. Mol. Ecol., 12, 1993-1998.

Harper, G. L., Maclean, N., Goulson, D. (2006). Analysis of museum specimens suggests extreme genetic drift in the Adonis blue butterfly (Polyommatus bellargus). Biol. J. Linn. Soc., 88, 447-452. 
Hendrich, L., Pons, J., Ribera, I., Balke, M. (2010). Mitochondrial Coxl sequence data reliably uncover patterns of insect diversity but suffer from high lineage-idiosyncratic error rates. PLoS ONE, 5 (12), e14448.

Howland, D. E., Hewitt, G. M. (1995). Phylogeny of the Coleoptera based on mitochondrial cytochrome oxidase I sequence data. Insect Mol. Biol., 4 (3), 203-215.

Isaac, N. J. B., Mallet, J., Mace, G. M. (2004). Taxonomic inflation: Its influence on macroecology and conservation. Trends Ecol. Evol., 19 (9), $464-469$

Kelly, R. P., Sarkar, I. N., Eernisse, J. D., Alle, D. R. (2007). DNA barcoding using chitons (genus Mopalia). Mol. Ecol. Notes, 7, 177-183.

Kotze, J. D., Brandmayr, P., Casale, A., Dauffy-Richard, E., Dekoninck, W., Koivula, M. J., Lövei, G. L., Mossakowski, D., Noordijk, J., Paarmann, V., Pizzolotto, R., Saska, P., Schwerk, A., Serrano, J., Szyszko, J., Taboada, A., Turin, H., Venn, S., Vermeulen, R., Zetto, T. (2011) Forty years of carabid beetle research in Europe - from taxonomy, biology, ecology and population studies to bioindication, habitat assessment and conservation. ZooKeys, 100, 55-148

Krishtalka, L., Peterson, T. D., Viegalis, J. B., Wiley, E. (2000). The green internet: A tool for conservation science. In: Conservation in the Internet Age: Strategic Threats and Opportunities (pp. 143-164). (J. Levitt, ed.). Island Press, Washington, DC.

Kubista, M., Andrade, J. M., Bengtsson, M., Forootan, A., Jonák, J., Lind, K., Sindelka, R., Sjöback, R., Sjögreen, B., Strömbom, L., Ståhlberg, A., Zoric, N. (2006). The real-time polymerase chain reaction. Mol. Aspects Med., 27 (2-3), 95-125.

Lemey, P., Salemi, M., Vandamme, A. M. (2009). The Phylogenetic Handbook: A Practical Approach to Phylogenetic Analysis and Hypothesis Testing. New York: Cambridge University Press. 723 pp.

Lindahl, T. (1993). Instability and decay of the primary structure of DNA. Nature, 362, 709-715.

Lueders, T., Friedrich, M. W. (2003). Evaluation of PCR amplification bias by terminal restriction fragment length polymorphism analysis of small-subunit rRNA and mcrA genes by using defined template mixtures of methanogenic pure cultures and soil DNA extracts. Appl. Environ. Microbiol., 69 (1), 320-326.

Maddison, D. R., Baker, M. D., Ober, K. A. (1999). Phylogeny af carabid beetles as inferred 18S ribosomal DNA (Coleoptera: Carabidae). Systemat, Entomol., 24, 103-138.

Maddison, D. R., Moore, W., Baker, M. D., Ellis, T. M., Ober, K. A., Cannone, J. J., Gutell, R. R. (2009). Monophyly of terrestrial adephagan beetles as indicated by three nuclear genes (Coleoptera: Carabidae and Trachypachidae). Zool. Scr., 38 (1), 43-62.

Mandrioli, M. (2008). Insect collections and DNA analyses: How to manage collections? Museum Management and Curatorship, 23, 193-199.

Margam, V. M., Gachomo, E. W., Shukle, J. H., Ariyo, O. O., Seufferheld, M. J., Kotchoni, S. O. (2010). A simplified arthropod genomic-DNA extraction protocol for polymerase chain reaction (PCR)-based specimen identification through barcoding. Mol. Biol. Rep., 37, 3631-3635.

Merzendorfer, H. (2013). Chitin synthesis inhibitors: Old molecules and new developments. Insect Sci., 20, 121-138

Received 5 January 2015
Morlais, I., Severson, D. W. (2002). Complete mitochondrial DNA sequence and amino acid analysis of the cytochrome c oxidase subunit I (COI) from Aedes aegypti. DNA Res,, 13, 123-127.

Muller, C. J., Beheregaray, L. B. (2010). Paleo island-affinities revisited-biogeography and systematics of the Indo-Pacific genus Cethosia Fabricus (Lepidoptera: Nymphalidae). Mol. Phylogen. Evol., 57, 314-326.

Raupach, M. J., Astrin, J. J., Hanning, K., Peters K. M., Stoeckle, M. Y., Wägele, J. W. (2010). Molecular species identification of Central European ground beetles (Coleoptera: Carabidae) using nuclear rDNA expansion segments and DNA barcodes. Front Zool., 7, 26.

Rohland, N., Siedel, H., Hofreiter, M. (2004). Nondestructive DNA extraction method for mitochondrial DNA analyses of museum specimens. Biotechniques, 36 (5), 814-821.

Sipos, R., Szekely, A. J., Palatinszky, M., Revesz, S., Marialigeti, K., Nikolausz, M. (2007). Effect of primer mismatch, annealing temperature and PCR cycle number on 16S rRNA gene-targetting bacterial community analysis. FEMS Microbiol Ecol., 60, 341-350.

Suarez, A. V., Tsutsui, N. D. (2004). The value of museum collections for research and society. BioOne, 54 (1), 66-74.

Sun, Y., Li, Q., Kong, L., Zheng, X. (2012). DNA barcoding of Caenogastropoda along coast of China based on the COI gene. Mol. Ecol. Res., 12, 209-218

Thomsen, P. F., Elias, S., Gilbert, M. T. P., Haile, J., Munch, K., Kuzmina, S., Froese, G. D., Sher, A., Holdaway, N. R., Willerslev, E. (2009). Non-destructive sampling of ancient insect DNA. PLOS ONE, 4 (4), e5048.

VanGuilder, H. D., Vrana, K. E., Freeman, W. M. (2008). Twenty-five years of quantitative PCR for gene expression analysis. Biotechniques, 44 (5), 619-626.

VanHardenbroek, M., Grocke, D. R., Sauer, P. E., Elias, S. A. (2012). North American transect of stable hydrogen and oxygen isotopes in water beetles from a museum collection. J. Paleolimnol., 48 (2), 461-470.

Wandeler, P., Hoeck, P. E. A., Keller, L. F. (2007). Back to the future: Museum specimens in population genetics. Trends Ecol. Evol.. 22 (12), 634-642.

Watts, P. C., Thompson, J. D., Allen, K. A., Kemp, J. S. (2007). How useful is DNA extracted from the legs of archived insects for microsatellite-based population genetic analyses? J. Insect Conserv., 1, 195-198.

Wiley, E. O., Lieberman, B. S. (2011). Phylogenetics: The Theory of Phylogenetic Systematics. New Jersey: John Wiley \& Sons Inc. 406 pp.

Willerslev, E., Cooper, A. (2005). Ancient DNA. Proceedings of the Royal Society of London B, 272, 3-16.

Willerslev, E., Hansen, A. J., Poinar, H. N. (2004). Isolation of nucleic acids and cultures from ice and permafrost. Trends Ecol Evol., 19, 141-147.

Winker, K. (2004). Natural history museums in a postbiodiversity era. BioScience, $\mathbf{5 4}$ (5), 455-459.

Wong, M. L., Medrano, J . F. (2005). Real-time PCR for mRNA quantitation. Biotechniques, 39 (1), 75-85.

Yuan, J. S, Donglin, W., Stewart, C. N. (2008). Statistical methods for efficiency adjusted real-time PCR quantification. Biotechnol. J., 3 (1), $112-123$.

Yuan, J. S, Reed, A., Chen, F., Stewart C. N. (2006). Statistical analysis of real-time PCR data. BioMed Centr. Bioinformat., 7, 85.

\section{REĀLA LAIKA POLIMERĀZES ĶĒDES REAKCIJA OPTIMĀLA TERMISKA PROFILA NOTEIKŠANAI DNS PARAUGIEM NO SAUSĀ KUKAIN̦U KOLEKCIJU MATERIĀLA}

Pētījumā tika novērtēta universālā mtDNS praimeru pāra HCO/LCO pievienošanās temperatūra DNS paraugiem no sausās kolekcijas 48 skrejvaboḷu Notiophilus ǵints īpatniem. Rakstā ir aplūkota reāla laika polimerāzes ḳēdes reakcijas metodika un tās iespējas optimālā termiskā profila noteikšanā, kad astoṇas dažādas praimeru pievienošanās temperatūras tika aprobētas. Pētījuma rezultāti parādīja, ka izdalītās DNS koncentrācija no sausā kolekciju materiāla ir l̦oti zema un ir augsts piemaisījumu līmenis, līdz ar to DNS sekvenču iegūšanai ir veikta polimerāzes k̦ēdes reakcijas termiskā profila optimizācija. Pētījuma gaitā tika iegūtas un gēnu bankā pievienotas no sausā kolekciju materiāla izdalīto DNS paraugu sekvences (kodi: KF060716, N. semenovi - KF060717 and N. jakovlevi - KF060718). 